九州大学学術情報リポジトリ

Kyushu University Institutional Repository

\title{
Importance-Performance Analysis of Forest Works for Sustainable Forest Management in Korea
}

Kang, Hag Mo

Gyeonggi-do Forest Environment Research Station

Lee, Sang Hyun

Faculty of Forest Science, Chonbuk National University

Yang, Byung Woo

Department of Agricultural Economics, Chonbuk National University

Choi, Soo Im

Korea Forest Research institute

他

https://doi.org/10.5109/9312

出版情報: 九州大学大学院農学研究院紀要. 52 (1)，pp. 255-263，2007-02-28. Faculty of Agriculture, Kyushu University

バージョン :

権利関係 : 


\title{
Importance-Performance Analysis of Forest Works for Sustainable Forest Management in Korea
}

\author{
Hag Mo KANG ${ }^{1}$, Sang Hyun $\mathrm{LEE}^{2 *}$, Byung Woo YANG ${ }^{3}$, Soo Im CHOI ${ }^{4}$, \\ Hyun Kim², Young Jin Cho ${ }^{2}$, Ho Sub LIM ${ }^{2}$ \\ and Noriko SATO
}

\author{
Laboratory of Forest Policy, Division of Forest Environment and Management Sciences, \\ Department of Forest and Forest Products Sciences, Faculty of Agriculture, \\ Kyushu University, Fukuoka 812-8581, Japan \\ (Received November 10, 2006 and accepted December 1, 2006)
}

\begin{abstract}
This study investigated residents' reaction to attributes of forest management using the Importance-Performance Analysis methodology in an attempt to identify attributes of forest management that should be a top priority to establish effective policy planning for sustainable forest management (SFM). This study was conducted during the 3 months in 2005 involving 328 residents living in Jangsu County and Namwon City, Korea.

Residents in Jangsu County considered 'forest tending', 'recreational forest and green tourism', 'preparing forest environment near residential areas', and 'conservation and management of forest ecological system' important, and were satisfied with management practices undertaken for these attributes. Residents in Namwon City citied 'afforestation of forest resources', 'structural establishment of forest management', 'maintenance of trees designated as natural monument' and 'integrated forest management (short term source of income)' in the same category.

This study highlighted residents' reactions to forest management practices in Jangsu and Namwon, both of which are well known for lumber production among non-national managed forest areas. This study suggests the possibility of making these mountainous areas as a regional model of effective forest management, because it provided valuable information that can be used for setting priorities and allocating resources for sustainable forest management. It is also important to implement forest policies palatable to characters of each region to achieve sustainable forest management. When implementing forest policy that meet the needs of each region, forest authorities are expected to fulfill the objectives of effective forest management.
\end{abstract}

\section{INTRODUCTION}

Sustainable forest management has emerged as the key paradigm shaping research and management practices undertaken for the 21st century forest environment. The United Nations Conference on Environment and Development (UNCE) embraced the concept of sustainable forest management in 1992 by declaring the forest resources and environment should be managed in a way that helps sustain social, economic, ecological, cultural aspects and mental comfort'. Thus, UNCE emphasized that health and sustainability of forests are related to broader aspects of human life beyond their economic value, calling for the need for global cooperation and responsibility (Korea Forest Research Institute, 2003). While UNCE developed new paradigm for the global forest environment, Korea introduced new plans and policy on forest management in 2004. To develop forest management plan to be pursued at provincial and municipal levels, it was necessary to examine the public forest management plans, including

${ }^{1}$ Gyeonggi-do Forest Environment Research Station, Osan, 447-290, Korea

${ }^{2}$ Faculty of Forest Science, Chonbuk National University, Chonju, 561-756, Korea

${ }^{3}$ Department of Agricultural Economics, Chonbuk National University, Chonju, 561-756, Korea

${ }^{4}$ Korea Forest Research Institute, Seoul, 130-712, Korea

* Corresponding author (E-mail: leesh@chonbuk.ac.kr)
Forest Vision 21, Basic Plans for Forest Management and Plans for Regional Forest, and offer management criteria and guidelines tailored to characteristics of each city and county.

Plans pursed by provincial and municipal governments for non-national managed forests need to encompass afforestation and management practices suitable for each region in the forest industry and structural tending techniques aimed to achieve effects of UNCE-initiated sustainable forest management (Korea Forest Service, 2003).

Forest management is controlled by the central government of Korea, and plans and guidelines for forest management are delivered from the central government to each provincial and municipal government. Thus, Plans and guidelines do not reflect forest characteristics of each city and county as a result. If each city and county were directly involved in establishing and implementing forest plans, they could come up with more effective measures for forest conservation and sustainability by taking into consideration forest characteristics of the region. Forest environments represent an important component of the ecological system, and demand on forest conservation to sustain human resting, preservation of water and ecology is outpacing demand on economic benefits of forest resources such as lumber. It is necessary to develop forest plans capable of achieving both environmental wellbeing and economic outcomes.

The purpose of this study, therefore, was to provide 
a basis for meeting the needs of residents to establish forest policy, and information required for sustainable forest management at provincial and municipal levels by investigating residents' reaction to forest policy.

\section{OBJECTIVES AND METHODS}

\section{Research Content and Scope}

\section{Research Content}

This study investigated residents' reactions to management practices undertaken for the forest environment of non-national forest 37,648 ha in Namwon and 32,427 ha in Jangsu County to provide basic information needed for sustainable forest management. Attributes of forest works for sustainable forest management are defined as shown in Table 1, and resident satisfaction and importance with each attribute was measured and analyzed.

\section{Methods}

Methods

A questionnaire was administered to 228 and 100 residents of Jangsu and Namwon, respectively. Their main job was forest owners and forest authorities in usual. The investigation questionnaire was done using a personal interview with the residents from September to November, 2005 for 3 months.

Importance-Performance Analysis

Collected data were analyzed in terms of importance and performance of management practices. The importance-performance analysis is a marketing research technique developed by Martilla and James (1977), and used to measure consumer's responses to attributes of goods and services and develop effective marketing strategies. That is, consumers' attitude is measured by asking them to rate the importance of attributes of goods or services before using them. After consumers

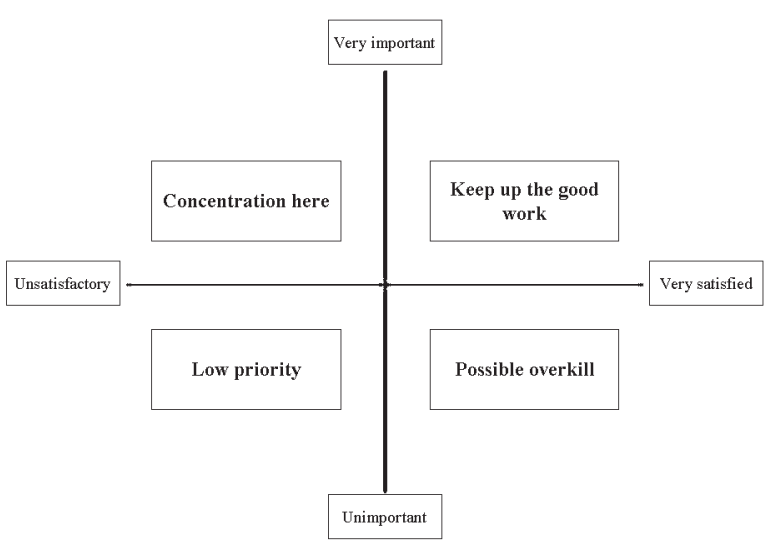

Fig. 1. Grid of I-P Analysis.

assess their performance after using the good or service, the importance of attributes is compared to degree of performance of consumers for each attribute.

In this study, residents' reaction to attributes of forest works is evaluated using the Importance-Performance Analysis, and data is presented on a $2 \times 2$ grid as shown Fig. 1 .

\section{RESULTS AND DISCUSSION}

\section{Social Characteristics of Subjects}

Jangsu County

Male subjects accounted for $74 \%$ of total respondents living in Jangsu County. By age, those in their 40s accounted for 29\%. By educational level, those with a high school diploma or above made up 36\%, and by income level, those with a monthly income of $\$ 1,000$ to $\$ 2,000$ made up 33\% (Table 2).

By occupation, those who are engaged in agriculture and working people in the private sector and public sec-

Table 1. Attributes of forest works for sustainable forest management

\begin{tabular}{|c|c|c|c|c|c|}
\hline \multirow{2}{*}{$\begin{array}{l}\text { Attributes } \\
\text { Attributes }\end{array}$} & \multicolumn{5}{|c|}{ Importance and Performance } \\
\hline & $\begin{array}{c}\text { Very } \\
\text { unsatisf } \\
\text {-actory } \\
\text { (Least } \\
\text { importa } \\
\text {-nt) }\end{array}$ & $\begin{array}{l}\text { Unsatisf } \\
\text {-actory } \\
\text { (Less } \\
\text { importa } \\
\text {-nt) }\end{array}$ & Neutral & $\begin{array}{l}\text { Satisfact } \\
\text {-ory } \\
\text { (Import } \\
\text { a-nt) }\end{array}$ & $\begin{array}{c}\text { Very } \\
\text { satisfact } \\
\text {-ory } \\
\text { (Very } \\
\text { importa } \\
\text {-nt) }\end{array}$ \\
\hline $\begin{array}{l}\text { A. Afforestation of forest resources } \\
\text { B. Forest tending } \\
\text { C. Forest infrastructure (forest road, mechanization) } \\
\text { D. Integrated forest management (short term source of income) } \\
\text { E. Producing professionals for forest management } \\
\text { F. Recreational forest and green tourism } \\
\text { G. Preparing forest environment near residential areas } \\
\text { H. Conservation and management of forest ecological system } \\
\text { I. Prevention of forest disaster } \\
\text { J. Structural establishment of forest management } \\
\text { K. Regional specialization using forest resources } \\
\text { L. Protection and management of water resources } \\
\text { M. Development of alternative energy using forest resources } \\
\text { N. Maintenance of trees designated as natural monument }\end{array}$ & & & & & \\
\hline
\end{tabular}


Table 2. Social factors of respondents in Jangsu

\begin{tabular}{|c|c|c|}
\hline Classification & Characteristics & Percentage (\%) \\
\hline \multirow{2}{*}{ Gender } & Male & 74 \\
\hline & Female & 26 \\
\hline \multirow{5}{*}{ Age } & Below 30 years, & 15 \\
\hline & 30-39 years & 25 \\
\hline & 40-49 years & 29 \\
\hline & 50-59 years & 19 \\
\hline & Above 60 years & 12 \\
\hline \multirow{5}{*}{ Education level } & Elementary school graduates or below & 8 \\
\hline & Junior high school graduates & 13 \\
\hline & High school graduates & 36 \\
\hline & Two-year college graduates & 15 \\
\hline & Four-year college graduates or above & 28 \\
\hline \multirow{4}{*}{ Monthly income } & Less than $\$ 1,000$ & 23 \\
\hline & $\$ 1,000$ to $\$ 2,000$ & 33 \\
\hline & $\$ 2,000$ to $\$ 3,000$ & 25 \\
\hline & More than $\$ 3,000$ & 19 \\
\hline
\end{tabular}

Table 3. Ownership of mountains, the size of mountain and presence or absence of forest income

\begin{tabular}{|c|c|c|}
\hline Classification & Feature & Percentage (\%) \\
\hline \multirow{2}{*}{ Ownership of mountain } & Yes & 66 \\
\hline & No & 34 \\
\hline \multirow{4}{*}{ Size of mountain owned } & Less than 1ha & 38 \\
\hline & 1 to below 5 ha & 37 \\
\hline & 5 to below 10 ha & 15 \\
\hline & More than 10ha & 10 \\
\hline \multirow{2}{*}{ Presence or absence from forest income } & Yes & 37 \\
\hline & No & 63 \\
\hline
\end{tabular}

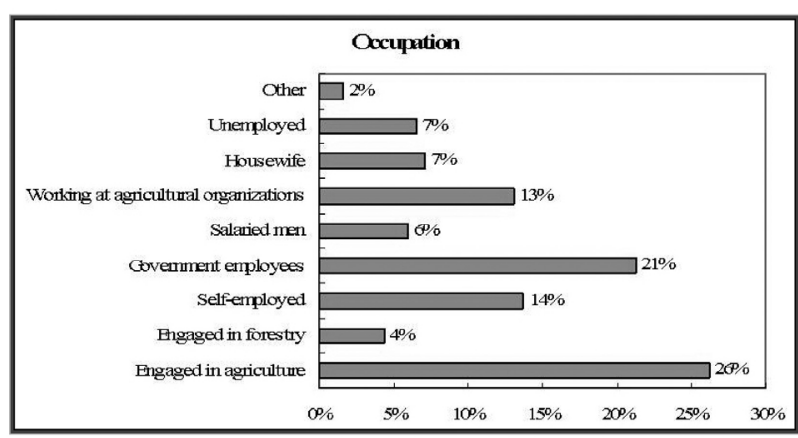

Fig. 2. Occupation of Jangsu County residents.

tor accounted for 30\% and 27\%, respectively (Fig. 2).

Of total respondents living in Jangsu County, 34\% owned a mountain and of those, 37\% said they had income generated from their mountains. Of those, $56 \%$ answered their income sourced from sales of trees, 17\% said their income arose from mushroom harvest and $9 \%$ responded their income generated from sales of nuts and fruits. These incomes sources differ from a general trend of making incomes from sales of forest by-products (Korea Forest Research Institute, 2004; Korean Forest Society, 2003). And a higher percentage of income sourced from sales of trees is attributed to mountainous topographical characters of Jangsu County, and suggest the possibility of boosting the development of lumber industry (Tables 3 and 4).
Table 4. Sources of forest income

\begin{tabular}{cc}
\hline Income sources & Percentage (\%) \\
\hline Lumber & 56 \\
Fruits and nuts & 9 \\
Mushroom & 17 \\
Wild vegetables & 9 \\
Other & 9 \\
\hline
\end{tabular}

Given the fact that lumber imports reached up $94 \%$ in South Korea, it is definitely necessary to support the development of lumber products in the area like Jangsu County.

When asked what expectations they had for their mountain, a larger number of forest owners intended to pass on their mountain to their decedents, and wished that the price of their mountains could rise. These findings are consistent with those commonly found among forest owners (Park et al., 2003). Of forest owners, 19\% wanted to see an increase in their income from forest products (Fig. 3).

Namwon City

Male subjects accounted for 94\% of total respondents living in Namwon City. By age, those in their 40s accounted for $67 \%$. Those with a high school diploma made up $88 \%$ and those with a monthly income of $\$ 3,000$ or above made up 39\% (Table 5).

By occupation, government employees accounted for $50 \%$ of total respondents in Namwon City, followed by those engaged in agriculture (39\%) and those work- 
Table 5. Social factors of respondents in Namwon City

\begin{tabular}{|c|c|c|}
\hline Classification & Characteristics & Percentage (\%) \\
\hline \multirow{2}{*}{ Gender } & Male & 94 \\
\hline & Female & 6 \\
\hline \multirow{5}{*}{ Age } & Below 30 years & 0 \\
\hline & 30-39 years & 3 \\
\hline & 40-49 years & 67 \\
\hline & 50-59 years & 22 \\
\hline & Above 60 years & 8 \\
\hline \multirow{5}{*}{ Education level } & Elementary school graduates or below & 6 \\
\hline & Junior high school graduates & 6 \\
\hline & High school graduates & 41 \\
\hline & Two-year college graduates & 8 \\
\hline & Four-year college graduates or above & 39 \\
\hline \multirow{4}{*}{ Monthly income } & Less than $\$ 1,000$ & 17 \\
\hline & $\$ 1,000$ to $\$ 2,000$ & 22 \\
\hline & $\$ 2,000$ to $\$ 3,000$ & 22 \\
\hline & More than $\$ 3,000$ & 39 \\
\hline
\end{tabular}

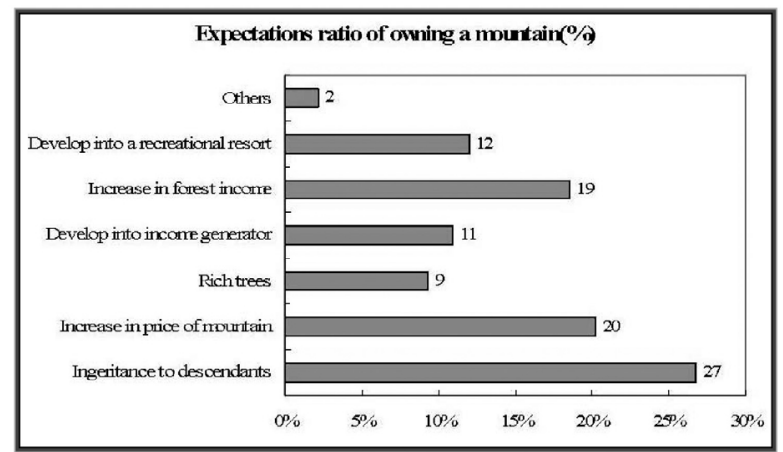

Fig. 3. Forest owners' expectations for their mountain.

ing at agricultural organizations (6\%) (Fig. 4).

Of total respondents, $42 \%$ owned a mountain. Of those, 20\% responded they had income generated from their mountain. By the size of mountain, a largest percentage of forest owners (46\%) owned a mountain with a surface area of 1 to 5 ha, which represent a typical mountain size owned by the majority of private forest owners across the nation (Table 6). By income source, $34 \%$ earned income by producing lumbers and 33\% earned income by harvesting mushrooms (Table 7). As a large number of people make income from lumber sales, Namwon is also considered having the potential for enhancing the lumber industry.

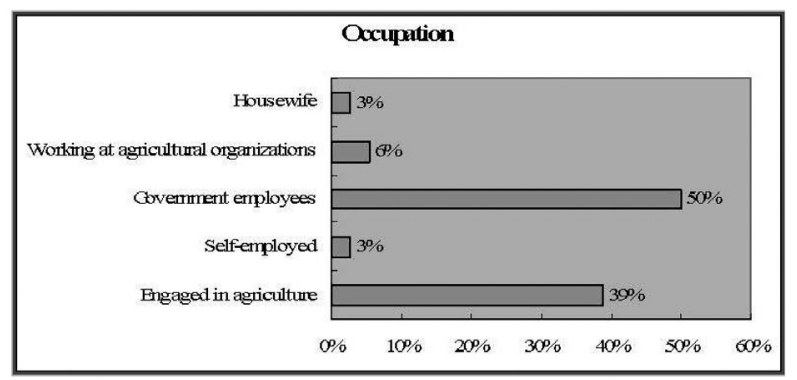

Fig. 4. Occupation of respondents in Namwon City.

When asked what expectations they had for their mountain, a larger number of forest owners wished that their forest-related income could rise (36\%). About $19 \%$ wanted to see that their mountain is transformed into a recreational resort and $17 \%$ intended to pass on their mountain to their decedents. These findings are not consistent with the general trend toward owning a mountain as a means of increasing wealth or asset. Thus, forest owners in Namwon City showed greater interest in increasing their forest income (Fig. 5).

Considering the tendency for private forest owners to be less enthusiastic about forest management, beneficial and economical effects of forest management can be demonstrated through the effective forest management model. And Namwon seems to be an ideal place to devise such a forest management model.

Table 6. Ownership of mountain, the size of mountain and presence or absence of forest-related income

\begin{tabular}{ccc}
\hline Classification & Feature & Percentage (\%) \\
\hline \multirow{2}{*}{ Ownership of mountain } & Yes & 42 \\
& No & 58 \\
\hline \multirow{2}{*}{ Size of mountain owned } & Less than 1 ha & 27 \\
& 1 to below 5 ha & 46 \\
& 5 to below 10 ha & 27 \\
\hline \multirow{2}{*}{ Presence or absence of forest income } & More than 10 ha & 20 \\
& Yes & 80 \\
\hline
\end{tabular}


Table 7. Sources of forest income

\begin{tabular}{cc}
\hline Income sources & Percentage (\%) \\
\hline Lumber & 34 \\
Mushroom & 33 \\
Other & 33 \\
\hline
\end{tabular}

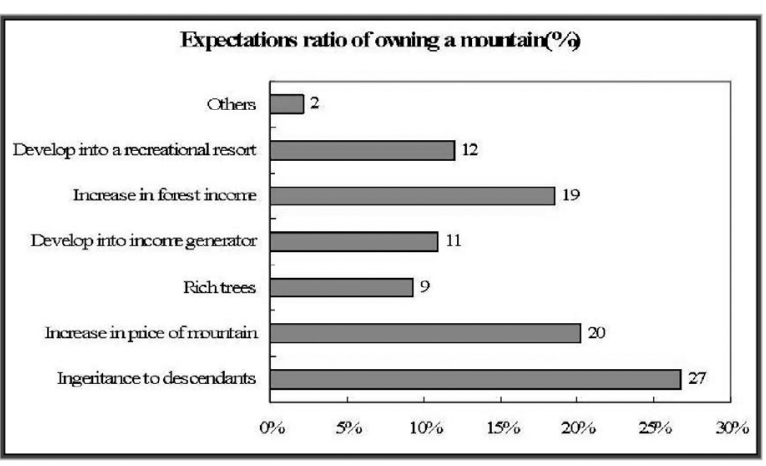

Fig. 5. Forest owners' expectations for their mountain.

\section{Respondents' Satisfaction with Major Forest Management Practices \\ Importance-Performance Analysis}

The Importance-Performance Analysis is used for evaluating forest management practices in this study. The IPA was mainly used to evaluate management practices undertaken for the creation of parks and recreational resorts in Korea (Shin, 1998; Lee et al., 2001; Song and Park, 2003). But this market research technique has been rarely used for forest management practices.

Results of the IPA are presented using a two dimensional matrix of $\mathrm{X}$ and $\mathrm{Y}$, where $\mathrm{X}$ is satisfaction (performance) and $\mathrm{Y}$ is importance. Since there is no differences between average value and median value of two dimensions, arithmetic mean scores of importance and performance were used as the starting point. Four sides of importance-performance grid are characterized as 'Keep up good work' , 'Concentrate here' , 'Low priority' and 'Possible overkill', respectively (Table 8).

\section{Grade of IPA Results between Jangsu and Namwon} Results of Importance-Performance Analysis in

\section{Jangsu County}

Respondents' reaction to forest management practices was measured on a 5-point scale in terms of importance and satisfaction. The mean score for overall satisfaction was 2.88, and a higher level of satisfaction was observed in 'recreational forest and green tourism' with mean score of 3.01, while a lower level of satisfaction was found in 'development of alternative energy using forest resources' with mean score of 2.69. The mean score for overall importance was 3.80 as respondents considered almost all attributes of forest management important. Respondents considered 'prevention of forest disaster' the most important showing the mean score of 4.07. Thus, respondents appeared to put higher importance on public benefits of forest management (Table 9).

Based on each attribute positioned on each side of the importance-performance grid, 'forest tending', 'recreational forest and green tourism', 'preparing forest environment near residential areas', and 'conservation and management of forest ecological system' belonged to Side 1 . This means that residents considered these attributes important, and they are satisfied with management practices undertaken for these attributes. It is, therefore, necessary for forest authorities to set priorities to allocate resources for new investment and management in relation to these attributes.

'Prevention of forest disaster' and 'regional specialization using forest resources' belonged to Side 2, meaning that the importance of these attributes are recognized but management practices are not performed properly given low levels of satisfaction. Forest authorities need make it a top priority to improve management practices for these attributes.

'Development of alternative energy using forest resources', 'afforestation of forest resources' and 'producing professionals for forest management' belonged to Side 3, which means low levels of importance and satisfaction. It is not, therefore, imminent to improve man-agement practices for these attributes.

'Forest infrastructure (forest road, mechanization)', 'protection and management of water resources', 'integrated forest management (short term source of income)' and 'maintenance of trees designated as natural monument' belonged to Side 4. This means that residents considered these attributes less important but

Table 8. Characters of each side of Importance-Performance grid

\begin{tabular}{cl}
\hline Side 1 (Keep Up Good Work) & $\begin{array}{l}\text { High levels of importance and satisfaction, so the current } \\
\text { attribute of forest management need to be maintained. }\end{array}$ \\
\hline Side 2 (Concentrate Here) & $\begin{array}{l}\text { Importance of the attribute is recognized but satisfaction is low, } \\
\text { so top priority is required for more investment and management to satisfy the } \\
\text { needs of forest owners. }\end{array}$ \\
\hline Side 3 (Low Priority) & $\begin{array}{l}\text { Low levels of importance and satisfaction, so the attribute needs to be considered } \\
\text { with low priority }\end{array}$ \\
\hline Side 4 (Possible Overkill) & $\begin{array}{l}\text { A low level of importance but a high level of satisfaction, so excess supports for } \\
\text { this attribute can be restrained }\end{array}$ \\
\hline
\end{tabular}


Table 9. Mean scores of each attribute

(5-point scale)

\begin{tabular}{lcc}
\hline \multicolumn{1}{c}{ Attributes } & Satisfaction & Importance \\
\hline A. Afforestation of forest resources & 2.83 & 3.72 \\
B. Forest tending & 2.94 & 3.98 \\
C. Forest infrastructure (forest road, mechanization) & 2.91 & 3.65 \\
D. Integrated forest management (short term source of income) & 2.89 & 3.74 \\
E. Producing professionals for forest management & 2.84 & 3.61 \\
F. Recreational forest and green tourism & 3.01 & 3.86 \\
G. Preparing forest environment near residential areas & 2.89 & 3.83 \\
H. Conservation and management of forest ecological system & 2.91 & 3.96 \\
I. Prevention of forest disaster & 2.84 & 4.07 \\
J. Structural establishment of forest management & 2.87 & 3.67 \\
K. Regional specialization using forest resources & 2.84 & 3.87 \\
L. Protection and management of water resources & 2.99 & 3.78 \\
M. Development of alternative energy using forest resources & 2.69 & 3.67 \\
N. Maintenance of trees designated as natural monument & 2.91 & 3.70 \\
\hline \multicolumn{2}{r}{ Mean score } & 3.80 \\
\hline
\end{tabular}

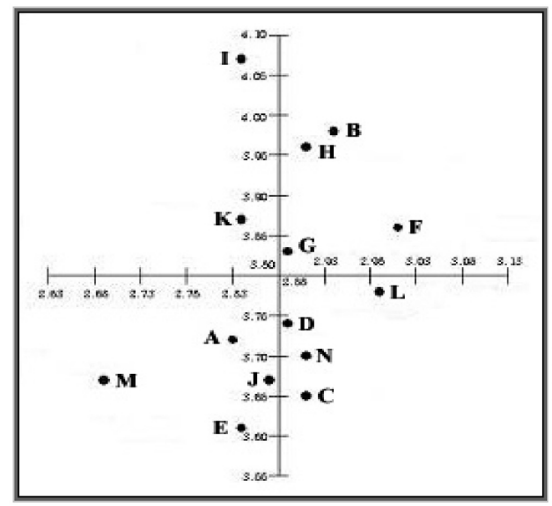

A : Afforestation of forest resources B : Forest tending $\mathbf{C}$ : Forest infrastructure(forest road, mechanization) D : Integrated forest management(shot term source of income) $\mathbf{E}$ : Producing professionals for forest management $\mathbf{F}$ : Recreational forest and green tourism $\mathbf{G}$ : Preparing forest environment near residential areas $\mathbf{H}$ : Conservation and management of forest ecological system $\mathbf{I}$ : Prevention of forest disaster $\mathbf{J}$ : Structural establishment of forest management $\mathbf{K}$ : Regional specialization using forest resources $\mathbf{L}$ : Protection and management of water resources $\mathbf{M}$ : Development of alternative energy using forest resources $\mathbf{N}$ : Maintenance of trees designated as natural monument

Fig. 6. Position of each attribute in the I-P grid in Jangsu County.

Table 10. Attributes positioned in the four sides of the I-P grid in Jangsu County

\begin{tabular}{|c|c|}
\hline Side & Attributes of Forest Works \\
\hline Side 1 & $\begin{array}{l}\text { - Forest tending } \\
\text { - Recreational forest and green tourism } \\
\text { - Preparing forest environment near residential areas } \\
\text { - Conservation and management of forest ecological system }\end{array}$ \\
\hline Side 2 & $\begin{array}{l}\text { - Prevention of forest disaster } \\
\text { - Regional specialization using forest resources }\end{array}$ \\
\hline Side 3 & $\begin{array}{l}\text { - Afforestation of forest resources } \\
\text { - Producing professionals for forest management } \\
\text { - Structural establishment of forest management } \\
\text { - Development of alternative energy using forest resources }\end{array}$ \\
\hline Side 4 & $\begin{array}{l}\text { - Forest infrastructure (forest road, mechanization) } \\
\text { - Integrated forest management (short term source of income) } \\
\text { - Protection and management of water resources } \\
\text { - Maintenance of trees designated as natural monument }\end{array}$ \\
\hline
\end{tabular}


had high levels of satisfaction. It is, therefore, necessary to contain resource consumption for these attributes (Fig. 6 and Table 10).

Results of Importance-Performance Analysis in Namwon City

The mean score for overall satisfaction was 3.14 among respondents living in Namwon City. A higher level of satisfaction was observed in 'afforestation of forest resources' with a mean score of 3.14 that reflecting the effects of management practices driven to improve afforestation. A lower level of satisfaction was found in " development of alternative energy using forest resources' with mean score of 2.86, which reflecting low recognition of the need for alternative energy among residents (Table 11).

The mean score for overall importance was 3.31 as respondents considered almost all attributes of forest management important. Respondents considered 'struc- tural establishment of forest management' the most important showing the mean score of 3.42 and 'integrated forest management (short term source of income)' the second most important. Thus, respondents were concerned about the possibility of using forest resources as a source of income.

Based on attributes positioned on each side of the importance-performance grid, 'afforestation of forest resources', 'structural establishment of forest management', 'maintenance of trees designated as natural monument' and 'Integrated forest management (short term source of income)' belonged to Side 1, indicating a top priority for investment and management in relation to these attributes.

'Protection and management of water resources' and 'prevention of forest disaster' belonged to Side 2, indicating the importance of these attributes is recog-nized but actual management practices were not

Table 11. Mean scores of each attribute

\begin{tabular}{lcc}
\multicolumn{1}{c}{ Attributes } & Satisfaction & Importance \\
\hline A. Afforestation of forest resources & 3.28 & 3.36 \\
B. Forest tending & 3.22 & 3.31 \\
C. Forest infrastructure (forest road, mechanization) & 3.06 & 3.28 \\
D. Integrated forest management (short term source of income) & 3.14 & 3.39 \\
E. Producing professionals for forest management & 3.08 & 3.31 \\
F. Recreational forest and green tourism & 3.08 & 3.31 \\
G. forest environment near residential areas & 3.22 & 3.19 \\
H. Conservation and management of forest ecological system & 3.22 & 3.28 \\
I. Prevention of forest disaster & 3.11 & 3.25 \\
J. Structural establishment of forest management & 3.03 & 3.42 \\
K. Regional specialization using forest resources & 3.11 & 3.28 \\
L. Protection and management of water resources & 2.86 & 3.36 \\
M. Development of alternative energy using forest resources & 3.25 & 3.25 \\
N. Maintenance of trees designated as natural monument & 3.14 & 3.33 \\
\hline Mean score & & 3.31 \\
\hline
\end{tabular}

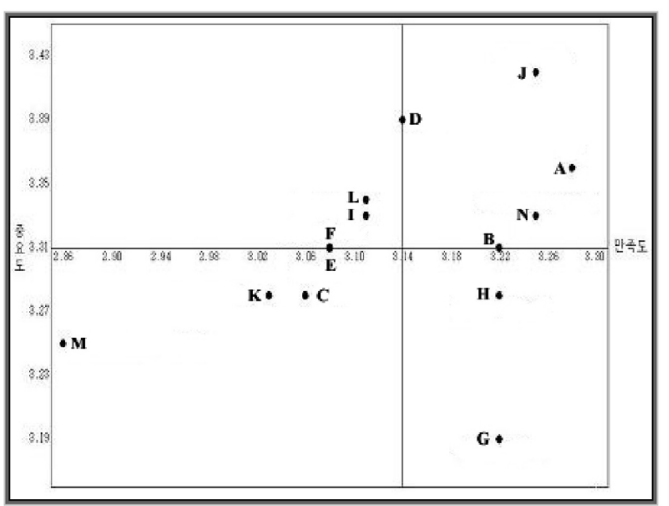

A : Afforestation of forest resources B : Forest tending $\mathbf{C}$ : Forest infrastructure(forest road, mechanization) $\mathbf{D}$ : Integrated forest management(shot term source of income) $\mathbf{E}$ : Producing professionals for forest management $\mathbf{F}$ : Recreational forest and green tourism $\mathbf{G}$ : Preparing forest environment near residential areas $\mathbf{H}$ : Conservation and management of forest ecological system $\mathbf{I}$ : Prevention of forest disaster $\mathbf{J}$ : Structural establishment of forest management $\mathbf{K}$ : Regional specialization using forest resources $\mathbf{L}$ : Protection and management of water resources $\mathbf{M}$ Development of alternative energy using forest resources $\mathbf{N}$ : Maintenance of trees designated as natural monument

Fig. 7. Position of each attribute in I-P grid in Namwon City. 
Table 12. Attributes positioned in the four sides of the I-P grid in Namwon City

\begin{tabular}{cl}
\hline Side & \multicolumn{1}{c}{ Attributes of Forest Works } \\
\hline & - Afforestation of forest resources \\
Side 1 & - Structural establishment of forest management \\
& - Maintenance of trees designated as natural monument \\
& - Integrated forest management (short term source of income) \\
\hline Side 2 & - Protection and management of water resources \\
& - Prevention of forest disaster \\
\hline & - Forest infrastructure (forest road, mechanization) \\
& - Producing professionals for forest management \\
& - Recreational forest and green tourism \\
& - Regional specialization using forest resources \\
& - Development of alternative energy using forest resources \\
& - Forest tending \\
& - Conservation and management of forest ecological system \\
& - Preparing forest environment near residential areas \\
\hline
\end{tabular}

satisfactory.

'Forest infrastructure (forest road, mechanization)', 'producing professionals for forest management' 'recreational forest and green tourism', 'regional specialization using forest resources' and 'development of alternative energy using forest resources' belonged to Side 3, which indicates that resources can be consumed with low priority for these attributes.

'Forest Tending', 'conservation and management of forest ecological system' and 'preparing forest environment near residential areas' belonged to Side 4, indicating a low level of importance and a high level of satisfaction. It is, therefore, necessary to contain resource consumption for these attributes (Fig. 7 and Table 12).

\section{CONCLUSION}

While sustainable forest management is emphasized in the international context, this study investigated residents' reaction to forest management practices in Jangsu County and Namwon City using the importance-performance methodology in an attempt to improve effectiveness of policy instruments for forest environment. Results of this study are summarized as follows:

(1) Residents in Jangsu County considered 'forest tending', 'recreational forest and green tourism', 'preparing forest environment near residential areas' and 'conservation and management of forest ecological system' important and were satisfied with management practices undertaken for these attributes. Residents in Namwon City citied 'afforestation of forest resources', 'structural establishment of forest management', 'maintenance of trees designated as natural monument' and 'integrated forest management (short term source of income)' as important attributes of forest management and showed a high level of satisfaction. It is, therefore, concluded that forest authorities need to set priorities for better investment or management practices rather than continue their current efforts to implement measures with respect to these attributes.

(2) Residents in Jangsu County considered 'prevention of forest disaster' and 'regional specialization using forest resources' important, but they considered management practices undertaken for these attributes were not satisfactory. Residents in Namwon City had 'protection and management of water resources' and 'prevention of forest disaster' in the same category.

(3) There were some attributes for which residents in Jangsu and Namwon showed low levels of importance and satisfaction. It is, therefore, not imminent to allocate resources for these attributes. Those attributes included 'development of alternative energy using forest resources', 'afforestation of forest resources', 'producing professionals for forest management' and 'structural establishment of forest management' in Jangsu, and 'forest infrastructure (forest road, mechanization)', 'producing professionals for forest management', 'recreational forest and green tourism', 'regional specialization using forest resources' and 'development of alternative energy using forest resources' in Namwon.

(4) There were attributes that requires further control over resource allocation due to a low level of importance but a high level of satisfaction. Those attributes included 'forest infrastructure (forest road, mechanization)', 'protection and management of water resources', 'integrated forest management (short term source of income)' and 'maintenance of trees designated as natural monumental' in Jangsu, and 'forest tending', 'conservation and management of forest ecological system' and 'preparing forest environment near residential areas' in Namwon.

This study highlighted residents' reactions to forest management practices in Jangsu and Namwon, both of which are well known for lumber production among 
non-national managed forest areas. This study suggests the possibility of making these mountainous areas as a regional model of effective forest management, because it provided valuable information that can be used for setting priorities and allocating resources for forest management. It is also important to implement forest policies palatable to characters of each region to achieve sustainable forest management. When implementing forest policies that meet the needs of each region, forest authorities are expected to fulfill the objectives of effective forest management.

\section{REFERENCES}

Korea Forest Research Institute. 2003 The direction of forest management in sustainable development periods

Korea Forest Research Institute. 2004 Supply \& demand and distribution structure of short income forest product
Korea Forest Service. 2003 The method of forest planning for local government

Korea Forest Society. 2003 Symposium on the income improvement of non-timber product

Lee, J. H., S. Y. Han and K. W. Shim. 2001 Application of Importance-Performance Analysis to Management of National Park Facilities. Journal of Korean Institute of Forest Recreation, 5 (2): 61-68

Martilla, J. A and J. C. James. 1977 Importance-Performance analysis. Journal of Marketing, 41 (1): 77-79

Park, T. S., D. C. Kim., M. W. Lee., S. S. Lee., Y. H. Lee., Y. H. Cho., S. Y. Kang., W. H.Beon and J. C. Woo. 2003. Forest management. Hyangmoonsa, Korea

Shin, W. S. 1998 Application of Observance-Influence Analysis Technique in a National Park Management. Journal of Korea Forestry Society, 87 (2): 211-219

Song, H. S and M. W. Park. 2003 Evaluation of Management for Anmeyon Island Recreational Forest Using Importance-Performance Analysis. Korea Parks and Recreation Society, 5 (2): 87-93 